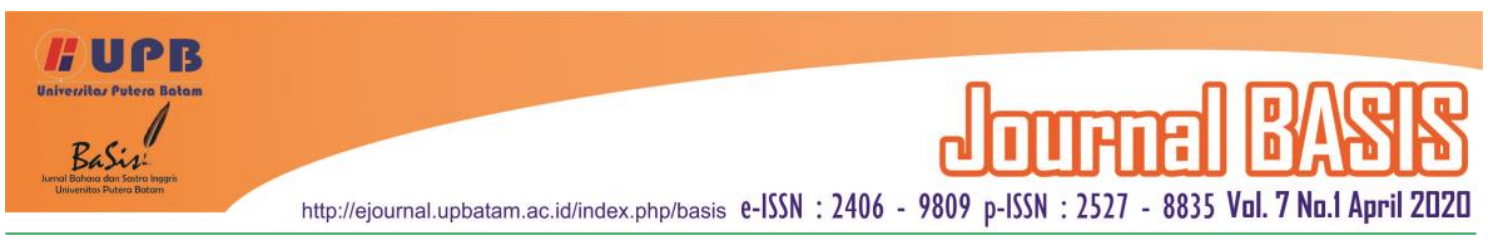

\title{
EFL LEARNER'S PRONUNCIATION PROBLEMS: A PHONOLOGICAL ANALYSIS
}

\author{
Valisneria Utami \\ IAIN Bengkulu, Bengkulu, Indonesia \\ valisneria@iainbengkulu.ac.id
}

\begin{abstract}
Many research concerning pronunciation problems of Chinese learners majorly take place within the country, yet very few of them conducted in the context where English is the native language of the country. This study aims to explore the problematic features of pronunciation of Chinese student who studied in Australian university. This study employs qualitative approach with a single case study. The data were collected through an interview and two models of speaking; monologue and reading a text. The problematic features, then, were prioritized based on its context and concept of English as International Language (EIL) context proposed by Jennifer Jenkins (2006). The result showed that the participant was aware about her pronunciation issues. Several problematic segmental and suprasegmental features in which emerged during data analysis also supported this finding. The problematic features are consonant

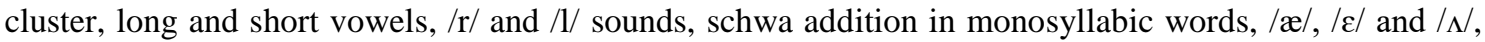
and issues in word stress, prominence, and intonation. Among all these features, the proposed prioritization of teaching is to focus on word stress, consonant cluster, intonation and prominence, /r/ and/l/, and long and short vowels. The findings also showed slightly difference in which in this study, the participant did not encountered difficulties in pronouncing double /1/ sounds. This study concludes with recommendation for teaching and learning these problematic features.
\end{abstract}

Keywords: Chinese student; problematic features; segmental; suprasegmental

\section{INTRODUCTION}

China occupied as the top five of international enrolment students in Australia however, English pronunciation is one of major obstacle which hinders them to be understood by native speaker or from English learners from other language background (Han, 2013). This evidence is quite contrary with the fact that English has become the compulsory subjects in China for many years and some of these learners have passed multiple English proficiency test to get an admission to the university.

Another findings also showed that pronunciation instruction as a part of teaching oral communication skills faced quite amount of challenges (Derwing, Diepenbroek, \& Foote, 2012) for example time constraint, insuficient training for teachers, or monotonous as a result of repetition and lack of communicative aspect. This present single case study attempt to investigate problematic features of English pronunciation of Chinese learner by analysing the prioritization of these problematic features and the suggested teaching technique. The prioritization can facilitate the English teachers or learners to be able to focus on particular features that are likely affect intelligibility. Furthermore, the suggested teaching techniques in this study offers a combination between controlled, guide, and independent activity to overcoming the major challenges in pronunciation teaching as above. 


\section{LITERATURE REVIEW}

2.1. The prioritization in teaching pronunciation

Having proper pronunciation is considered as an indicator of outstanding language mastery. Some English standardized test such as TOEFL and IELTS is also regarded this feature as one of the key elements in assessing speaking skill (Henderson et al., 2012). However, based on the recent studies from classroom observation and teachers' interview (Baker, 2011; Foote, Holtby, \&Derwing, 2011; Fraser, 2000; Yagiz, 2018) both in ESL and EFL context demonstrated that teaching pronunciation seems receive minimum attention in the classroom.

Particulary for teachers in EFL context, this reluctance is caused by two major factors; firstly, teachers' lack of self-confidence as a result of insufficient training and their status as non-native English teachers (Yuan \& Bai, 2018; Gergiou, 2019). In the comparative study between native (NS) and nonnative (NNS) teachers conducted by Ying and Ghouzi (2016), the result even presented that the Chinese learners favor NS in comparison to the local teacher as their pronunciation instructors. They felt that NS could be a better model and they could capture the "native accent".

Nevertheless, still from similar study, from the pronunciation test it showed an intriguing finding. The result indicated that the participants' pronunciation improved significantly after taught by NNS teachers. Thus, it can be concluded that local teachers, indeed, possess an immense potency in prounciation teaching. They have sufficient knowledge of their first language and certainly share similar culture with the learners. They can be more sensitive if there is a confusion by giving explanation in their L1. Overall, it seems that from pedagogical perspective, NNS teachers are able to teach English pronunciation as excellent as NS.

Secondly, time constraint. While teachers in EFL context is bounded by time in which may limit oral communication practice in the classroom, in ESL context, the learners are exposed to sounds of NS inside and outside of the classroom. As a result, this bring consequence in terms of what kind of pronunciation features that need to be incorporated in the classroom according to its context.

Considering how ample the pronunciation features and how it majorly affected by learners'L1, the studies of prioritization of teaching pronunciation is necessary as an attempt to overcoming these challenges Several studies suggested that both segmental (consonant and vowels) and suprasegmental features ( prominence, ryhtym, and intonation) should be included in pronunciation instruction (Moedjito, 2016). Another expert also claimed that teaching melody (suprasegmental) should be considered as necesssary as teaching individual sounds because these features are likely affecting meaning (Burri, 2015). Jenkins (2006) in her study proposed three main features of pronunciation that has major impact in intelligibility which are certain segmental, nuclear stress, and effective use of articulatory setting. Having said that, certain group of pronunciation features might not become priority to particular group of learners in particular context and vice versa. Every group of learners and context needs to be carefully examined to determine the prioritization.

\subsection{Chinese Learners Pronunciation.}

Previous studies of mispronunciation of Chinese learners 
has demonstrated a comprehensive description of segmental issues (Han, 2013; Bian, 2013; Zhang et.al; 2015; Ambalegin \& Hulu, 2019). However, these studies does not take account of much implication in pedagogy nor does it examine the context or position of English nowadays. For example, it suggested that the teacher utilize some technique such as minimal pairs and jazz chant. This focus only very little element of pronunciation, says, vowels or consonant but receive minimum impact on intelligibility. Whereas according to Pan (2012), it becomes evidence that Chinese learners are also struggling with suprasegmental issues such as word stress, intonation, etc. These features in English language learning holds a vital function to differentiate meaning and it is likely impossible by teaching them only with by the technique as mentioned before.

Furthermore, the prioritization of problematic features seems absence in the previous study. Prioritization holds a significant role in pronunciation teaching. In the context of EFL or traditional classroom in China and other similar countries, English lesson is bounded by time-constraint in which may limit pronunciation teaching Whereas, the learners still need to enhnace their oral communication skills. In other words, despite teaching all features of pronunciation, the teachers should examine and justify the main features that are likely affect intelligibility.

The motivation for this study is the gap in the literature on prioritization of problematic features and teaching techniques in the classroom. It also intends to confirm and to add about what literatures has presented.

The current study addressess three research questions:
1. What are problematic pronunciation features encountered by Chinese student in speaking English?

2. What is the prioritization of these features that are likely going to affect the intelligibility and comprehensibility?

3. What are the suggested pronunciation activities or tasks in overcoming these problems?

\section{METHODOLOGY}

This study employed a case study from a single participant. The purpose of this case study is to investigate the problematic features of Chinese learner in pronunciation according to the context and what are the suggested activities to minimize the problems. According to Yin in Tsevi (2018), a case study enables the researcher to examine and interview people who have roles to play in the study.

Furthermore, the researcher employed speaking tasks and an interview in this study. Maxwell (2005) recommended that to get needed information from interviews, it is important to build harmonious relationship with the participants. Thus, beside as the researcher, I positioned myself as an international student who understand the situation and share similar story about challenges in communicating in English.

\subsection{Participant}

Before conducting this study, the researcher tried to reach several international students randomly however none of them were willing their pronunciation skill to be analyzed. One of the reason because they had participated in this study in the previous semester. The researcher, then, contacted one of her colleague in 
Indonesian Students Association (ISA) and asking if she had an acquaintance, an international student who was interested in participating in this study. After several days contacting, there was one student who agreed to participate in this study.

This study was approved by the

Social Science HRECs (Human Research Ethics) of University of Wollongong. An international postgraduate student was interviewed and asked to perform two types of speaking tasks. The participant consented to participate in this research and signed the consent forms. The identity of the participant was not exposed in the study to guarantee confidentiality and privacy.

The participant was Valerie (pseudonym), a female postgraduate student from China. She is majoring in applied finance, Faculty of Business, in University of Wollongong (UOW), Australia. Before she enrolled, she had completed an English for Academic Purposes (EAP) course in UOW College. During her study, she lived by herself in on-campus dormitory.

\subsection{Data Collection Technique}

a. Interview

The researcher interviewed the participant at a time when she was not heavily burdened by the academic and social issues by letting her to schedule her own time and venue for the interview. The aim was to allow her a relaxed situation, to speak freely and to reflect on her experiences in learning English pronunciation and her engagement in oral communication skills. The interview was conducted in the morning and in one of study room in UOW Library.
The interview also intended to provide the researcher with the information about participant her selfawareness about her pronunciation skills. The questions of interview were adapted from UCLA students' questionnaire taken from Teaching Pronunciation Course Book: A Course Book and Reference Guide (2nd edition) written by Marianne CelceMurcia, Donna M. Brinton, Janet M.Goodwin with Barry Grinner.

The interview was lasted for 30 - 40 minutes. It was recorded and transferred from audio recorder to laptop. After that, the audio was transcribed by typing in Microsoft Word and participant was given an opportunity to review the transcription. This also functioned as member checking for triangulation of data (Harvey, 2015). After reviewing, the participant was provided the copies of the transcription to ensure that what she said has been captured accordingly.

\section{b. Speaking Task}

After conducting the interview, the subject were agreed to perform speaking task in the same day. There were two types of speaking tasks; performing free speech for five minutes and reading a text. Both tasks were audio recorded and the researcher did not interrupt during the process of data gathering, for instance, correcting the pronunciation mistakes or showing confusion when the participant spoke. 
In the first tasks, the participants shared her personal story about her dreams to pursue higher education degree overseas as it is also her family expectation. She also shared her experiences failing in an interview with one of scholarship provider from German. However, she determined to apply again next year and improved herself by took an IELTS class after she quit learning English after she earned bachelor degree.

In the second task, the participant read the text taken from "Diagnostic Passage and Accent Checklist" in Teaching Pronunciation Course Book: A Course Book and Reference Guide (2nd edition) written by Marianne Celce-Murcia, Donna M. Brinton, Janet M. Goodwin, with Barry Grinner. This text was developed by the authors as a tool for diagnose learner's problematic features in pronunciation such as vowelconsonants, sentence stress, rhythm, intonation, etc. Before she read, the researcher gave her some times to read the text by heart and comprehend the text.

\subsection{Data Analysis}

After the data was gathered, the interview was analyzed. According to Creswell in Tsevi (2018), data analysis involves a process making sense out of text. Thus, the researcher carefully read all the interview transcript several times, highlighted statements appeared, and looked for the patterns. The transcription was lso coded as "challenges/obstacles" and "effort". The result of this analysis is necessary in giving a researcher an insight in ordering the problematic features and presenting suggested activity.

For the speaking tasks, after transcription the analysis was done manually and the data were divided into two categories which were segmental (vowels and consonants) and suprasegmental features (stress, sentence stress, prominence, intonation and rhythm). To get an apparent result, the researcher was focused only on one feature at a time. The researcher also utilized "Oxford Advanced Learner's Dictionary" as a guide in analyzing the problematic feature and consulted with Course Lecturer to get better insight. The result then tabulated in a table and ordered based on the context of English is spoken as well as the number of this feature appeared. In introducing the suggested activities, it was developed from Baker's study (2013) in which she claimed that pronunciation instructionn can be boring due to over-routine. She suggested to include communicative, guided, and controlled tasks so it can enhance students' communicative skills.

\section{RESULT AND DISCUSSION}

4.1. Interview result

Valerie, 28 years old, was a postgraduate student who came from China. From the interview, she told that she began learning English since primary school as compulsory subject until first year in the university. Before she came to Australia, she didn't continue to learn English for three to four years, then she continued to learn English in a private class in Beijing, China. Her English proficiency was around at intermediate level. Prior to this study, Valerie has lived in Australia for 1,5 years.

Furthermore, she admitted that she felt more relaxed when talking with her international friends and classmates about the school and life experiences. 
She also mentioned that she was aware about her difficulty in pronouncing /ð/, $/ \theta /, / \mathrm{r} /$, and $/ \mathrm{l} /$ sounds, however she did not consider it as an anxious experience when talking to native speakers. She also wished to have the fluency like NS and determined to practice more and engaged with conversation with local people.

\subsection{Pronunciation Problematic features}

The first question in this research was what the problematic features in English pronunciation for Chinese learner are. The figure below is the description of problematic segmental and suprasegmental features from the two speaking tasks. T1 refers to unscripted story and $\mathrm{T} 2$ refers to read speech.

Figure 4.1. Problematic segmental features

\begin{tabular}{|c|c|}
\hline $\begin{array}{l}\text { Problemati } \\
\text { c Feature }\end{array}$ & $\begin{array}{l}\text { Examples (indicate script/time } \\
\text { codes) }\end{array}$ \\
\hline $\begin{array}{l}\text { 1.Consona } \\
\text { nt cluster }\end{array}$ & $\begin{array}{l}\text { 1. Children /'tfild/, T2 } \\
(0: 36) \\
\text { 2. } \begin{array}{l}\text { Couple /'k } \mathrm{kp} /, \mathrm{T} 2 \quad( \\
0: 27)\end{array}\end{array}$ \\
\hline $\begin{array}{l}2 . \quad \text { ii/ and } \\
/ \mathrm{I} /\end{array}$ & $\begin{array}{l}\text { 1. First: /first/ instead of } \\
\text { /'f3:st/, T2 ( 0:29) } \\
\text { 2. Detail: /'diterl/ } \\
\text { instead of /'di:terl/, } \\
\text { T1 (1:47) }\end{array}$ \\
\hline $\begin{array}{l}\text { 3. /v/ and } \\
\text { /f/ }\end{array}$ & $\begin{array}{l}\text { 1. Effective: /I' fektıf/, } \\
\text { T2 (1:50) } \\
\text { 2. Improving: } \\
\text { /Imprufiy/, T2 (1:30) } \\
\text { 3. Native: /'notıf/, } \\
\text { T2 }(00: 14,1: 43)\end{array}$ \\
\hline 4. /r/ and /1/ & $\begin{array}{l}\text { 1. All: /or/ instead of } \\
\text { /'ol/, T2 }(1: 24)\end{array}$ \\
\hline $\begin{array}{l}5 . / \mho / \text { and } \\
/ \mathrm{u} /\end{array}$ & $\begin{array}{l}\text { 1. University:/ } \\
\text { junivəsitı/ instead of } \\
\text { /,ju:ni'v3:siti/, T1 } \\
(2: 00)\end{array}$ \\
\hline
\end{tabular}

\begin{tabular}{|c|c|}
\hline $\begin{array}{l}\text { 6. Schwa } \\
\text { in } \\
\text { monosyllab } \\
\text { ic words } \\
\text { (and, just, } \\
\text { was \& is) }\end{array}$ & 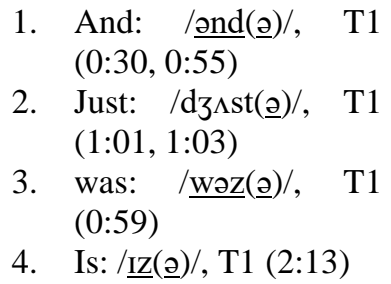 \\
\hline $\begin{array}{l}\text { 7. } / æ /, / \varepsilon / \\
\text { and } / \Lambda /\end{array}$ & $\begin{array}{l}\text { 1. Native: /nıtıf/ and } \\
\text { /nctif/, T2 (00:14, } \\
\text { 1:43) } \\
\text { 2. Language: } \\
\text { /lıygwidz/, } \\
(00: 15)\end{array}$ \\
\hline
\end{tabular}

Figure 4.2. Problematic suprasegmental features

\begin{tabular}{|c|c|}
\hline $\begin{array}{l}\text { Problema } \\
\text { tic } \\
\text { Features }\end{array}$ & $\begin{array}{l}\text { Examples (indicate script/time } \\
\text { codes) }\end{array}$ \\
\hline $\begin{array}{l}\text { 1. Word } \\
\text { stress }\end{array}$ & $\begin{array}{lr}\text { a. } & \text { INterview, T1 } \\
(00: 19) & \\
\text { b. } & \text { chiNESE,T1 (00:35) } \\
\text { c. } & \text { REcognize, T2 } \\
(01: 05) & \\
\text { d. } & \text { AuSTRAlia, T1 } \\
(00: 26) & \end{array}$ \\
\hline $\begin{array}{l}\text { 2.Prominen } \\
\text { ce }\end{array}$ & $\begin{array}{l}\text { [--] Ummm so but after that/ [R- } \\
\text { F] I feel like I really need to } \\
\text { review all of theyou know } \\
\text { knowledge that I learn from } \\
\text { university from the books/ [R-F] } \\
\text { and fortum (fortunately?) I also } \\
\text { you know I brought all of my } \\
\text { books from my university to } \\
\text { Beijing/ [R-F] so for the next um } \\
\text { the second exam is the was like } \\
\text { three months after the first exam } \\
\text { T1: 1:48 }\end{array}$ \\
\hline $\begin{array}{l}3 . \\
\text { Intonation }\end{array}$ & $\begin{array}{l}{[\mathrm{R}] \text { Is English your native }} \\
\text { language? T2 (0:15) } \\
{[\mathrm{R}+\mathrm{R}+\mathrm{F}] \text { In the end } \underline{\text { improving }}} \\
\text { improving appears to be a } \\
\text { combination of three things/ } \\
\text { concentrate the hard work/ a good } \\
\text { ear/ and a strong ambition to } \\
\text { sound like native speaker } \\
\text { T2 }(1: 30)\end{array}$ \\
\hline
\end{tabular}

The figure 1 presented the result of analysis problematic segmental features 
found in the recording. Among twenty four consonant sounds in English, the participant encountered difficulties in pronouncing $/ \mathrm{r} /$ and $/ \mathrm{v} /$ sounds. She changed $/ \mathrm{r} /$ to $/ \mathrm{l} /$ sounds as well as $/ \mathrm{v} /$ to /f/ sounds. Similarly, from twenty vowels sounds, it showed that participant experienced an issue in differentiating long and short vowels. In addition, it was also found that she voiced the consonant in monosyllabic word such as: and /'ond/ become

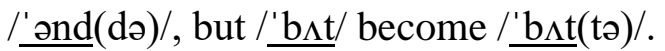

Furthermore in the figure 2 , the result showed that many times the participant pronounced the words with the incorrect placement of stress such as INterview become interVIEW, ChiNESE and REcognize without stress. This leads to a challenge in identifying where the prominence or thought group is. From the recording, it was also found that the participant did not utilize proper intonation to differentiate statements and questions.

The finding above supported the previous researches about the main difficulties of Chinese learners in English pronunciation (Avery et.al, 1987;Chang, 2001;Huang \& Radant, 2009;Zielinski \& Yates, 2009). One major contributing factor is due to negative transfer of the first language (L1). When the learner have to pronounce certain English consonant for example the word ending with $/ \mathrm{r} /$ or when they voiced the consonants, they had to find corresponds of these sounds in their L1. Consequently, it affects their intelligibility in oral communication (Ho, 2003). Furthermore, Chinese also has a different vowel system from English. Chinese does not differentiate $/ \mathrm{i}-\mathrm{I} /, / \mathrm{u}-\mho /, / \varepsilon /-/ \mathfrak{x} /$, or $/ \mathrm{N} /-\mathrm{p} /$ and vowel duration (long and short) is not functioned as a meaning making as in
English phonological system (Zhang, Feng, Dang, Zheng, \& Xu, 2017).

Another research also showed that Chinese has no distinction between long and short vowel and it has different stress and intonation pattern. A comparative study of English and Chinese intonation indicates that English sentence is composed by one or more than one tone units and each of the units has a prominence or a nuclear tone. In contrast, unit of intonation in Chinese is frequently referred as a sentence and marked by a tone at the final of the sentence (Pan, 2012). Thus, due to this difference, the Chinese learners usually pay more attention to the end of the sentence when forming and pronouncing English sentence and they do not accustomed to raise-falling the intonation from the prominence.

However, in contrast to earlier findings, there was no evidence of disability in differentiating $/ \mathrm{n} /$ and $/ \mathrm{l} /$ sounds as well as sound of /1/ like in "bill", "tell", and "well" in final syllable except "all" as in Chang's study in 2001. In this study, the participant likely needs to improve her supra-segmental features because it majorly affected intelligibility (Gilbert, 2008).

\subsection{Prioritization of problematic features}

The second objectives of this research was to order these problematic features based on the context and priority. In this case, the priority is justified according to the theory proposed by Judi Gilbert (2008). She stated that if the goal of pronunciation is to produce the sounds more intelligible and understandable, it is suggested to include supra-segmental features (prosody) in the pronunciation teaching. Thus the order is as follows: 


\section{a. Word Stress}

The study in the area of lexical stress has become evidence that correct placement of stress in word has a major impact into the intelligibility of nonnative speaker speech (Celce-Murcia, Brinton, Goodwin, \& Griner, 2010). In other words, when the stress is misplaced, the important clue to help listener decode meaning are missing. This part is considered the first priority in choosing the most problematic features. In Chinese, stress is not as significant as in English because this feature does not carry different meaning like its function in English (Bian, 2013).

b. Consonant cluster $(/ \mathrm{d} /$ and $/ \mathrm{r} /$, $/ \mathrm{p} /$ and $/ 1 /$ )

Having a consonant group in Chinese words is rarely found; therefore it is considered the priority in pronunciation teaching. In the speech sample, it was found that the Valerie was difficult to pronounce this feature such as "children", "couple", and "people". This finding resonated with Jang's study (2001) which showed that consonant cluster are problematic features when Chinese learners learn English. This feature is more troublesome and learners are likely to make additional syllables or simplify the cluster.

c. Intonation and prominence

Previous scholars agreed that the use of pitch and melody provides the most supra-segmental effects in language. It can effectively determine the sentence unit as well as to provide coherence between larger informal units. It also helps the speaker to convey the message effectively and express speaker's feeling, mood, attitude, and emotion. This feature is part of the prioritization because Chinese learners tend to use intonation in the end of sentence. This leads to the lack of intelligibility because it difficult to the listener to identify the idea they want to convey. Furthermore, by prioritize intonation in the pronunciation teaching it helps to produce the effect of prominence that can mark the word as the most important in the tone-unit (Pan, 2012)

d. $/ \mathrm{r} /$ and $/ \mathrm{l} /$

This particular sound has become a common issue for Chinese learners because it affects the intelligibility of the production of the whole sounds. From the speech analysis, it is also found that the interviewee makes some mistake in this area although it only happens two times. However, if this particular feature is not prioritized, it can affect the quality of the consonant sound and might convey different meaning, for example, when the subject says "all" /or/ instead of /' ol/

e. Long and short vowels

According to Kenworthy (1988), Chinese learners struggle in producing some vowel sounds such as /i/ and /I/, $/ \mathrm{N}, / \mathrm{a} /$, and $/ \mathrm{o} /$. It is undeniable since in the Chinese vowel system, there is only five to eight vowels compare to English (18 vowels) (Celce-Murcia et.al, 2010) Although, in this study the sounds of vowel produced by the subject is intelligible, these features needs to be included because quality of the sounds (in which may affected the word's meaning) is determined by the correct position of tongue, lip position, and vowel length (Underhill, 2005).

The problematic features above are prioritized based on the context of English as Second Language (ESL) where the participant of this study was doing her postgraduate study in Australia and exposed to the sounds of native speakers inside and outside the classroom. However, considering that English nowadays serve a role as an international language (EIL) for speaker who do not share similar native 
language, it is also necessary to rearrange the prioritization. In the context of EIL, intonation and long short vowels should be omitted in pronunciation instruction due to several reasoning:

First of all, based on Jenkins study (2006), there are three major features of pronunciation that has major impact to the intelligibility, which are certain segmental, nuclear stress (the main stress in a word group), and the effective use of articulatory setting underpins these two areas. Having said that, if the learners apply English to communicate with other international speakers, certain particular consonant feature such as $/ \theta /$ and $/ ð /$ might not become priority as well as some vowel features (long and short). The main reason is because other non-native speakers of English probably encounter difficulties and these features might not appear in the sound system in their first language (L1).

Secondly, in theory of development Second Language Acquisition (SLA), the stages start from "silent period" in which the learners build up their vocabulary first, the gradually moves to "early production", "speech emergence", "intermediate fluency", then "advanced fluency" (Stefansson, 2013). In contrast, in the process of acquisition of L1, the infants began with vocalization to babbling speech (Steinberg and Sciarini, 2005) in which they follow the intonation contours of the language from their parents or caretaker. Having said that, intonation is specifically embedded to L1 and it is likely impossible to teach this features considering how diverse English speakers in international setting although there are several studies suggests native-speaker pronunciation may well be-achieved by adults (Steinberg and Sciarini, 2005).

\subsection{Suggested teaching and learning technique}

After identifying the problematic features and examining the prioritization, the last objective of this study is the suggested teaching techniques as an attempt to make the pronunciation sounds more intelligible and comprehensible. This suggested activity is also proposed according to the Baker study in 2013. She suggested to incorporate communicative and guided activity in the classroom.

Firstly, in teaching and learning word stress, the first step is the learners have to be able to differentiate between stressed and unstressed syllables (CelceMurcia, 2010). To raise students' awareness, the teacher can apply audio recognition activity by giving $g$ the students a set of word list in English with combination of two or three syllable then asked them to circle or underline where the stress is by listening to the clip or the teacher can read aloud the word. For more advanced learners, the teacher can modify the activity by adding the number of syllable and the students have to decide how many syllables for each words.

Another activity is by using rubber band. Rubber band functioned as a visual image of the length of syllable. According to Gilbert (2008), it mimics the actual effort in lengthening a stressed syllable, so the students can avoid pronouncing each syllable at the same length. For Chinese learners, it is a typical common problem that can affect their intelligibility. They usually can lengthen a syllable but cannot shorten a syllable (Chen, Fan, \& Lin, 1998). The teacher can ask the students to pull a rubber widely between two thumbs when saying a word in English or for more advanced learners they can use it in practicing the dialogue or saying a longer sentence. This activity is 
also can be done individually for adult or more advance learners.

Secondly, in learning /r/ and /l/ sounds, teachers or learners can utilize face diagram with the aims to raise the students' awareness in producing the particular consonant sounds by placing parts of mouth and throat and how they restrict, interrupt or divert airflow (Kelly, 2000). It should be note that in explaining the face-diagram, the teacher needs to modify the language according to the level of the learners and using terms that they can understand. For example, for sound $/ 1 /$, instead of saying it is voiced liquid alveolar, the teachers or learners can repeat syllable such as lalalalalala for modeling how to place their speech organ.

For more communicative activity, the storytelling can be applied. The teacher can give 10 to 20 words and ask them to create a story from the list to their classmates and they take turn in telling the story. Another scenario can be one student telling the story and their friends can check whether the words pronounce correctly and whether they make sense in the context of the story (Celce-Murcia, 2010).

Thirdly, in learning intonation Chen (2013) pointed out that intonation is the one of the weakness area of oral communication for Chinese learners. Therefore, he suggested teaching intonation should be visualized. One of the technique is haptic intonation (touchinami). This activity integrates movement and touches to minimize the negative random gestures at the same time it aims for improving learner's intelligibility (Acton, Baker, Burri, \&Teaman, 2013). The technique has three basic intonation movements (level, rise, and fall) and two compound contours (rise fall, fall rise). The student has to say the sentences while at the same time move their hands together to show the intonation pattern.

After the learners are confident practicing intonation by mimicking the intonation pattern by using Touchinami technique, they will gain more confidence to try a role play on a similar situation. They just mimicking or they can create their own role play. This kind of activity can show the learners how similar they sound to a native speaker. Thus, it is suggested that the role-play is recorded. By doing so, it can show the progress that the learners made and provide valuable information for instructor to give feedback for them (Celce-Murcia, et al, 2010).

For learning consonant cluster, the learner can begin with understanding the basic information about English syllable structure such as V (eye), CV (see), CVC (can), CVCC (hurt), etc. It is because compare to English, majorly other languages has the simpler or simplest syllable structure (Celce-Murcia, et al, 2010). Another technique can be asked the students to work in pairs to come up with as many words for combination of two or three consonants for example CCCVC (splash: cluster of three). The teacher also can apply role play activity by using copy of calendar and make an agenda for each day. This activity can increase the interaction and improve their intelligibility (Celce-Murcia, 2010). The students then can practice the consonant clusters in ordinals numbers, for example:

A: "What is your plan on the third day of this month?"

B: "Well, I have a couple of things to do. I have a spin class and have to buy some groceries."

Lastly, for learning long and short vowels, vowel discrimination activity can be applied in the classroom. The students can circle the words they 
have listened and the teacher can level up the difficulties by pronouncing homophones and the learners decide if these two words are the same. Another activity is story strip. This task is basically asked the students to re arrange the jumbled sentences into story in which they have to pay attention carefully to the vowel contrast. The students are divided into groups and each individual has one strip of sentence that they have to memorize, then within their small groups, they have order the story. In this activity, it is recommended that the teacher utilized colors to highlight the vowel and to show the contrast among vowels.

\section{CONCLUSION}

This study demonstrates that there is a slightly changes in problematic features of English pronunciation for Chinese learners in comparison to previous study specifically in double /1/ sounds. The analysis of speech in this study also reveals that the prioritization of problematic features is varied based on the context (ESL or EIL), therefore it can be served as a fundamental information before justifying the priority. The findings can also be highlighted in training non-native English teacher to prepare for their pronunciation teaching and for English learners for self-studying or for those who intends to pursue their education or career in ESL countries and engage in international community.

Furthermore, this research is also not necessarily to make generalization for all English learners from China. Thus, this research can be expand and modify from many variables, for instance, examining contributing factors affecting pronunciation problems, increasing the number of subject involved and time length of the study, or having the subjects from another international setting and being examined by other international TESOL practitioner with the aims to enrich the previous studies

\section{REFERENCES}

Acton, W., Baker, A., Burri, M., \& Teaman, B. (2013). Preliminaries to haptic-integrated pronunciation instruction. In J. M. Levis \& K. LeVelle (Eds.), Proceedings of the 4th Pronunciation in Second Language Learning and Teaching Conference, Aug. 2012. (pp. 234244). Ames, IA: Iowa State University. Retrieved from http://jlevis.public.iastate.edu/psllt conference/4th\%20Proceedings/A ctonBakerBurriTeaman\%20PSLL T\%202012.pdf.

Ambalegin., \& Fasaaro, H. (2019). EFL Learners' Phonological Interference of English Articulation. Journal BASIS. 6(2), p. 145-154. Retrieved from http://ejournal.upbatam.ac.id/i ndex.php/basis/article/view/1 $415 / 858$

Avery, P. et al. (1987). Problems of selected language groups. TESL talk: The teaching of pronunciation: An introduction for teachers of English as a second language. USA: TESL Talk

Bai, B., \& Yuan, R. (2018). EFL Teachers' Belief and Practices about Pronunciation Teaching. ELT Journal. 73(2), p. 134-143. Retrieved from https://academic.oup.com/eltj/art icleabstract/73/2/134/5150649?redir ectedFrom=fulltext 
Bian, Fuying. (2013). The Influence of Chinese Stress on English Pronunciation Teaching and Learning. English Language Teaching. 6(11) p. 199-211. Retrieved from https://files.eric.ed.gov/fulltext/E J1078438.pdf

Burri, M. (2015). Students Teachers' Cognition about L2 Pronunciation Instruction: A Case Study. Australian Journal of Teacher Education, 40(10). Retrieved from https://files.eric.ed.gov/fulltext/EJ 1078747.pdf

Celce-Murcia, M., Brinton, D. M., Goodwin, J. M., \& Griner, B. (2010). Teaching pronunciation: A reference for teachers of English to speakers of other languages (2nd ed.). Cambridge: Cambridge University Press.

Chang, J. (2001). Chinese Speakers, in Swan, M. \& Smith, B. (eds.), Learner English: A Teacher's Guide to Interference and Other Problems, Cambridge University Press, New York: 224-237.

Derwing, T., M., Diepenbroek, L., G., \& Foote, J., A. (2012). How Well do General-Skills ESL Textbooks Adress Pronunciation?. TESL Canada Journal/Revue TESL $d u$ Canada. 30(1), p. 22-44. Retrieved from https://files.eric.ed.gov/fulltext/EJ 1001889.pdf

Gergiou, P., G. (2019). EFL Teachers' Cognition about Pronunciation in Cyprus. Journal of Multilingual and Multicultural. 40(6), p.538550. Retrieved from https://www.tandfonline.com/doi/ abs/10.1080/01434632.2018.1539

090

Gilbert, J. (2008). Teaching pronunciation: Using the prosody pyramid. Available at: http://www.tesol.org/connect/tesol -resource-center/searchdetails/teachingtips/2013/11/06/teachingpronunciation-using-the-prosodypyramid

Han, Feifei. (2013). Pronunciation of Chinese Learners of English. ORTESOL Journal. 30. p. 26-30. Retrieved from https://files.eric.ed.gov/fulltext/EJ 1152473.pdf

Huang, Hui-ling., \& Radant, James. (2009). Chinese Phonotactic Patterns and Pronunciation Difficulties of Mandarin-Speaking EFL Learners. Asian EFL Journal, Quarterly December, p. 115-279. Retrieved from https://www.asian-efljournal.com/mainjournals/chinese-phonotacticpatterns-and-the-pronunciationdifficulties-of-mandarin-speakingefl-learners/

Jenkins, J. (2002). A sociolinguistically based, empirically researched pronunciation syllabus for English as an international language. Applied Linguistics, 23(1), 83103. Retrieved from https://eric.ed.gov/?id=EJ641289

Kenworthy, Joanne. Teaching English Pronunciation: Longman Handbooks for Language Teachers. UK: Longman Group. 
Li, Y., \& Zhang, G. (2016). Native or Non-native-speaking Teaching for L2 Pronunciation Teaching? An Investigation on Their Teaching Effect and Students' Preferences. English Language Teaching. 9(12), p. 89-97. Retrieved from https://files.eric.ed.gov/fulltext/EJ 1120687.pdf

Liang, Danxin. 2015. Chinese Learners' Pronunciation Problems and Listening Difficulties in English Connected Speech. Asian Social Science, 11(16), p. 98-106.

Retrieved from http://www.ccsenet.org/journal/in dex.php/ass/article/view/49977

Moedjito. (2016). The Teaching of

English Pronunciation:

Perceptions of Indonesian School

Teachers and University Students. English Language Teaching. 9(6), p. 30-41. Retrieved from http://www.ccsenet.org/journal/in dex.php/elt/article/view/59572

Pan, Qi. (2012). The Comparative Study on English and Chinese Intonation. Theory and Practice in Language Studies. 2(1), p. 161164. Retrieved from http://www.academypublication.c om/issues/past/tpls/vol02/01/24.p $\mathrm{df}$

Stefansson, E., G. (2013). Second language acquisition: The effect of age and motivation. Retrieved from:

https://scholar.google.com/scholar $? \mathrm{hl}=$ en\&as_sdt $=0 \% 2 \mathrm{C} 5 \& \mathrm{q}=\mathrm{Secon}$ $\mathrm{d}+$ Language + Acquisition+The+Ef fect+of + Age+and + Motivation\&bt nG
Steiberg, D., D., \& Sciarini, N., V. (2006). An Introduction to Psycholinguistics: $2^{\text {nd }}$ edition. UK: Pearson Education Limited.

Underhill, Adrian. (2005). Sounds Foundations: Learning and Teaching Pronunciation. UK:Macmillan Education.

Ustunbas, Umran. (2018). Does Pronunciation Instruction Make Any Sense? EFL Learners and Teachers' Beliefs. International Journal of Curriculum and Instruction. 10(1), p. 71-84. Retrieved from https://files.eric.ed.gov/fulltext/EJ 1207244.pdf

Yagiz, O. (2018). EFL Language Teachers' Cognitions and Observed Classroom Practices about L2 Pronunciation: The Context of Turkey. NovitasROYAL (Research on Youth and Language). 12(2), p. 187-204. Retrieved from https://files.eric.ed.gov/fulltext/EJ 1195280.pdf

Yates, L., \& Zielinski, B. W. (2009). Give it a go: Teaching pronunciation to adults. Sydney: AMEP Research Centre. Available from http://www.ameprc.mq.edu.au/ data/assets/pdf_file/0011/157664/i nteractive_sm.pdf

Zhang, Aihui, et.al (2015). The perception of English vowel contrasts by Chinese EFL learners and native English speakers. Retrieved from: http://www.internationalphonetica ssociation.org/icphs- 
proceedings/ICPhS2015/Papers/I

CPHS0651.pdf 